\title{
Directed Evolution of Artificial Metalloenzymes: Genetic Optimization of the Catalytic Activity
}

\author{
Martina Hestericová
}

SCS-Metrohm Award for best oral presentation in Catalysis Science \& Engineering

\begin{abstract}
Artificial metalloenzymes (ArMs) based on the incorporation of a biotinylated metal cofactor within a streptavidin (Sav) combine attractive features of both enzymatic and homogeneous catalysis. To speed up their optimization, we present a directed evolution of an artificial transfer hydrogenase (ATHase) based on a streamlined and optimized protocol for the design, overexpression and screening of Sav isoforms. Ten positions have been subjected to mutagenesis to yield two variants with improved catalytic activity and selectivity for the reduction of cyclic imines, along with greater stability in a biphasic medium.
\end{abstract}

Keywords: Artificial metalloenzymes · Cyclic imines · Directed evolution · Enzyme catalysis · Transfer hydrogenation

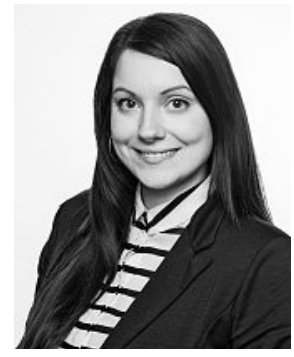

Martina Hestericová was born in Slovakia. She studied biochemistry and bioorganic chemistry at the Comenius University in Slovakia, focusing her work on solvent-free organocatalysis. After receiving her Diploma under guidance of Prof. Radovan Sebesta, she joined the research group of Prof. Thomas R. Ward at the University of Basel as a PhD candidate. She is currently working on optimization of artificial metalloenzymes for nanoapplications.

\footnotetext{
${ }^{\star}$ Correspondence: M. Hestericová Department of Chemistry, University of Basel Mattenstrasse 24a, BPR 1096, CH-4002 Basel E-mail: martina.hestericova@unibas.ch
}

Catalysis represents an essential technique in synthetic organic chemistry. Thanks to its extraordinary value, various synthetic systems, including organocatalysts, heterogeneous solids, enzymes and metal complexes, have been developed. ${ }^{[1]}$ Biocatalytic use of enzymes, either in the whole cell format, contained in cell lysates or as purified proteins, has proved useful in multiple industries, such as fine and bulk chemicals, cosmetics, textile, pulp and paper, food and pharmaceuticals. [2]

Chiral amines serve as important intermediates in synthesis of fragrances and flavors, agrochemicals and biologically active compounds. Since approximately $40 \%$ of all pharmaceuticals contain at least one chiral amine building block, ${ }^{[3]}$ the demand for their enantioselective synthesis is immense and multiple methods are available. Current strategies to produce enantiopure amines include resolution of racemates, ${ }^{[4]}$ organic synthesis ${ }^{[5]}$ or biocatalysis. ${ }^{[6]}$ Biocatalytic production of chiral amines can be achieved by direct enzymatic synthesis using phenylalanine ammonia lyases, ${ }^{[7]}$ transaminases, ${ }^{[8]}$ imine reductases, ${ }^{[9]}$ and amine dehydrogenases, ${ }^{[10]}$ or by dynamic kinetic resolution by implementing lipases, ${ }^{[11]}$ or monoamine oxidases. ${ }^{[12]}$ Industrial use of imine reductases represents a challenge, which is predominantly caused by the restricted amount of available enzyme types, their price, finite substrate scope and low stability of their substrates in water or buffer. Development of novel imine reductases and optimization of their catalytic performance is therefore highly desirable.

Artificial metalloenzymes (ArMs) are created by incorporating a synthetic metal cofactor within a protein or a DNA scaffold.[13] Multiple anchoring strategies are available:[14] covalent, non-covalent, dative, and metal substitution. Since ArMs comprise a biological and synthetic part, the performance of both components can be optimized independently. The selection of the macromolecular protein or DNA scaffold determines the anchoring strategy and the methods for its genetic optimization, whereas the rationally designed synthetic cofactor determines which type of reaction could be performed. ${ }^{[15]}$ The (strept) avidin-biotin (Sav-biot) technology[16] has been established as a very versatile anchoring strategy for the preparation of ArMs. Following the initial reports of ArMs technology by Wilson and Whitesides in $\left.1978,{ }^{[13 g}\right]$ multiple catalytic systems have been realized. These include allylic alkylation, ${ }^{[17]} \mathrm{C}-\mathrm{H}$ activation, ${ }^{[15 b]}$ metathesis, ${ }^{[18]}$ dihydroxylation, [19] alcohol oxidation, ${ }^{[20]}$ sulfoxidation, [21] hydrogenation, [13f,22] and transfer hydrogenation. ${ }^{[23]}$ Noteworthy, some of these reactions do not exist in biological systems, ArMs have therefore brought new-to-nature chemical transformations into enzymatic catalysis. ${ }^{24]}$ Artificial Transfer Hydrogenase (ATHase) has received an increased amount of attention, which resulted in their application in reduction of enones and ketones, and, more recently, of imines, $\mathrm{NAD}(\mathrm{P})^{+}$and its analogs.

To mimic the natural process of enzyme evolution, directed evolution ${ }^{[25]}$ was established by Arnold, Chen, ${ }^{25 h]}$ and Stemmer[25i] almost two decades ago. Since then, this powerful method has been used to fine-tune the selective formation 
of enantiomers, broaden the substrate acceptance of enzymes or to improve their stability in a targeted manner. This versatile methodology, comprising iterative cycles of mutagenesis followed by protein expression and their screening, can also be applied in the evolution of hybrid catalysts, allowing for their Darwinistic progression (Fig. 1).[25e]

The development of high-throughput screening methods for evolution of ArMs has a bottleneck; the E. coli cellular environment contains millimolar concentrations of glutathione (GSH) and other metabolites capable of poisoning the soft metal-containing catalyst.[26a] Screening utilizing protein purification is therefore often necessary. Since the workload increases exponentially with the increasing library size, a system circumventing the protein purification stage is highly desirable. Our group has recently described a streamlined optimization protocol ${ }^{[16 a]}$ that allows parallel in vivo expression of Sav in $E$. coli in a 24-deep well plate format. The cells are grown in an autoinduction medium based on low amounts of glucose and high amounts of lactose. Upon consuming glucose, the expression of the recombinant protein is induced by lactose during the exponential growth phase, which allows for automated protein production without the need for manual induction. After cell harvest and lysis, the resulting cell free extracts (cfe) are treated with diamide (1,1-azobis(N,N-dimethylformamide, DiAm). This GSH scavenger capable of oxidizing GSH to glutathione disulfide (GSSG) notably recovers the catalytic performance ${ }^{[26 b]}$ when applied to cfe prior to the addition of the metal cofactor. Building upon this technique, we selected an area of $10 \AA$ around the iridium center of the biotinylated cofactor anchored within the Sav active site and subjected the corresponding amino acids to targeted mutation. Our efforts in directed evolution of the ATHase resulted in four generations of mutant variants, which showed improved activity in transfer hydrogenation of various cyclic imine substrates.[23a]

Based on our previous screening results, mature Sav with alanine at position 121 was selected for the library generation. In the first round of directed evolution, a reduced library of amino acids constituting of A, V, L, D, E, Q, K, H, M, Y, S, P, and $\mathrm{N}$ was introduced at positions T111, S112, G113, T114, A116, N118, S122, T123 and L124. In the following generations, all canonical amino acids were individually introduced relying on precise primers. The resulting mutants were overexpressed in $E$. coli using an autoinduction medium in 24-deep well plates. The harvested cells were lysed and the concentration of the

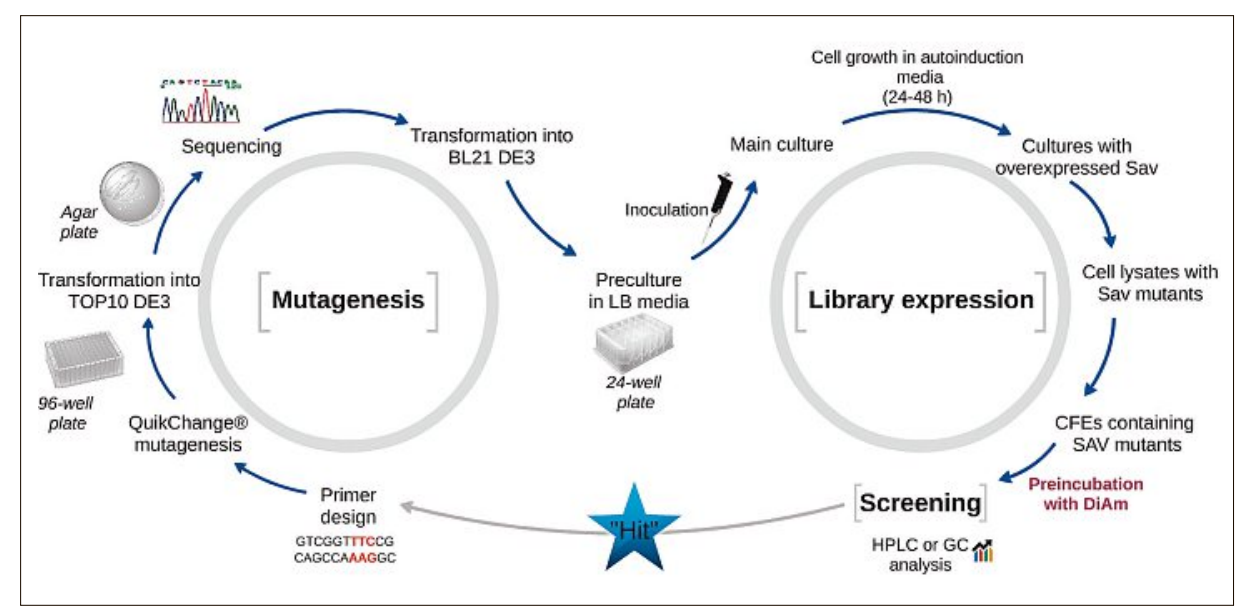

Fig. 1. Workflow for directed evolution of ArMs. Mutagenesis based on precise primers is followed by expression in E. coli. The lysed cells are treated with DiAm prior to the addition of a biotinylated cofactor, which leads to the constitution of an active artificial metalloenzyme with an ATHase activity. After screening and identification of a 'hit', the mutation of interest is used as a template for another round of mutagenesis. biotin free binding sites in the resulting cfe was determined by means of a biotin4-fluorescein absorption-fluorescence assay. ${ }^{[16 b, 27]}$ The extracts were consequently treated with DiAm followed by the addition of $[\mathrm{Cp} * \operatorname{Ir}($ biot $-p-\mathrm{L}) \mathrm{Cl}]$ and screened for their ATHase activity a cyclic imine substrate (Fig. 2). After identification of a successful 'hit', the results were reproduced, the corresponding mutant overexpressed in 1L shaking flasks, purified using an iminobiotin affinity chromatography column and confirmed by screening in MOPS buffer (3-(morpholino)propanesulfonic acid) using sodium formate as the hydride source. In these experiments, the ratio between $\mathrm{Sav}$ and $[\mathrm{Cp} * \operatorname{Ir}($ biot $-p-\mathrm{L}) \mathrm{Cl}]$ was fixed to $2: 1$ to ensure optimal reaction rate and the selectivity. ${ }^{[28]}$

The first-generation screening revealed two mutants with an improved activity. In the reduction of $\mathbf{1}$, an $(S)$-selective mutant

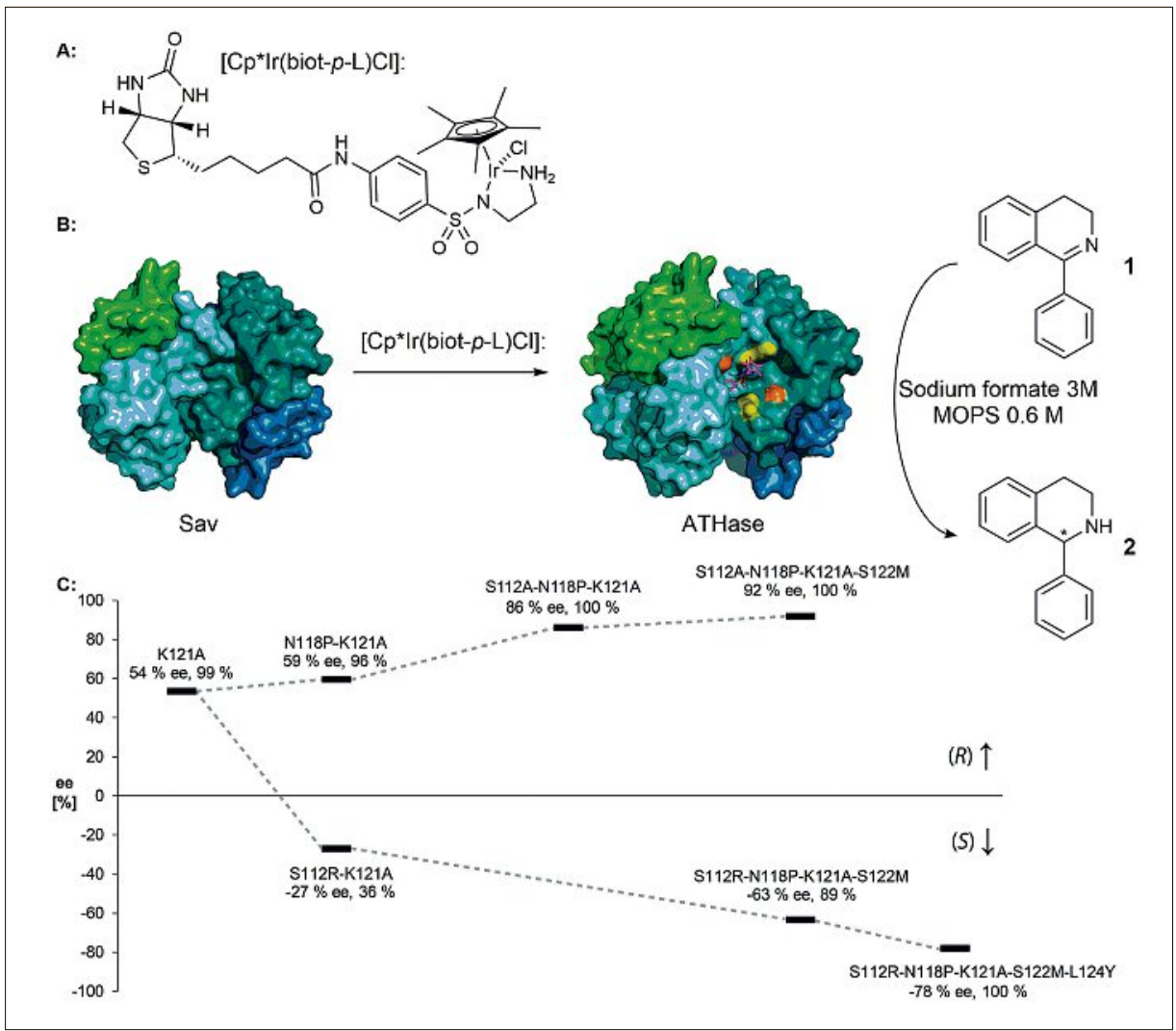

Fig. 2. Directed evolution of ATHase. (A) Structure of the biotinylated pianostool Cp*Ir cofactor. (B) ATHase is created upon incorporation of the biotinylated cofactor within Sav. (C) Directed evolution tree of ATHase of a model cyclic imine 1. 
Table 1. Reduction of substrate 1 catalyzed by various ATHases using purified proteins. ${ }^{a}$

\begin{tabular}{|c|c|c|c|c|}
\hline Entry & ATHase & conv. [\%] & TON & ee [\%] \\
\hline 1 & {$[$ Cp*Ir(biot- $p$-L)Cl] } & 17 & 35 & - \\
\hline 2 & K121A & 99 & 198 & $54(R)$ \\
\hline 3 & K121A ${ }^{[c]}$ & 5 & 100 & $31(R)$ \\
\hline 4 & N118P-K121A & 96 & 193 & $59(R)$ \\
\hline 5 & S112R-K121A & 36 & 72 & $-27(S)$ \\
\hline 6 & S112A-N118P-K121A & 100 & 200 & $86(R)$ \\
\hline 7 & S112A-N118P-K121A-S122M & 100 & 200 & $92(R)$ \\
\hline 8 & S112A-N118P-K121A-S122M & $100\left(70^{\mathrm{d}}\right)$ & 200 & $91(R)$ \\
\hline 9 & S112A-N118P-K121A-S122M & 19 & 380 & $95(R)$ \\
\hline 10 & S112R-N118P-K121A-S122M & 90 & 179 & $-63(S)$ \\
\hline 11 & S112R-N118P-K121A-S122M-L124Y & 100 & 200 & $-78(S)$ \\
\hline 12 & S112R-N118P-K121A-S122M-L124Y & $75\left(55^{\mathrm{d}}\right)$ & 150 & $-72(S)$ \\
\hline 13 & S112R-N118P-K121A-S122M-L124Y & 11 & 220 & $-85(S)$ \\
\hline & & & & \\
\hline
\end{tabular}

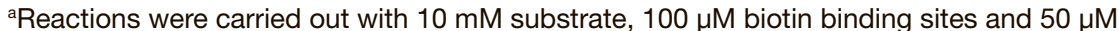
[Cp*Ir(biot-p-L)Cl] at $37^{\circ} \mathrm{C}$ for $48 \mathrm{~h}$ in $0.6 \mathrm{M} \mathrm{MOPS}$ and $3 \mathrm{M}$ sodium formate at $\mathrm{pH} 6 .{ }^{\circ}$ Reactions were carried out on a preparative scale (>120 mg of 1) in $60 \mathrm{ml}$. 'Reactions were carried out using a biphasic set-up with $100 \mathrm{mM}$ substrate at RT for 4 days. dsolated yield.

S112R-K121A (Table 1, entry 5) was identified along with an $(R)$-selective mutant N118P-K121A (entry 4), which was subjected to saturation mutagenesis at position S112. In the resulting second generation, mutant S112A-N118P-K121A yielded $(R)-2$ in $86 \%$ ee and full conversion (entry $6)$. Introducing an additional substitution of serine to methionine at position 122 in the third generation further improved the selectivity and yielded $(R)-2$ in $92 \%$ ee (entry 7).

The $(S)$-selective route was evolved starting from the arginine-containing mutant S112R-K121A. Upon introducing proline at position 118 and methionine at position 122, the selectivity for $(S)-2$ was increased to $63 \%$ ee (entry 10). In the last generation, the introduction of tyrosine at position 124 as a second bulky residue within the Sav active site further improved the $(S)$-selectivity and the mutant S112R-N118P-K121A-S122M-L124Y yielded $(S)-2$ in $78 \%$ ee and full conversion (entry 11).

Preparative scale experiments, performed in degassed buffer and with $>120$ $\mathrm{mg}$ of substrate, resulted in full conversion (GC; 70\% after purification) and $91 \%$ ee $(R)$ for S112A-N118P-K121A-S122M Sav (entry 8 ) and $75 \%$ conversion (GC; $55 \%$ after purification) and $72 \%$ ee $(S)$ for S112RN118P-K121A-S122M-L124Y Sav (entry 12). Due to the low water solubility of the cyclic imine selected for screening, experiments in a biphasic set up using 100 $\mathrm{mM}$ of substrate were performed. Both most evolved Sav variants performed better in the terms of enantioselectivity and turnover number (TON) (entries 9 and 13) compared to mutant K121A, representing the starting point of our directed evolution (entry 3).

Analysis of the obtained X-ray structure of $[\mathrm{Cp} * \operatorname{Ir}($ biot- $p-\mathrm{L}) \mathrm{Cl}]$. S112AN118P-K121A-S122M suggests formation of the catalytically active hydride form of $\mathrm{Cp} * \mathrm{Ir}$ cofactor in $(R)$-configuration. The non-concerted transition state grants a formation of a $\mathrm{CH} \cdots \pi$ interaction between the substrate and the $\mathrm{Cp}^{*}$ moiety of the catalyst, thus predominantly producing the $(R)$-enantiomer of $\mathbf{2}$. The crystal structure of $\left[\mathrm{Cp}^{*} \operatorname{Ir}(\right.$ biot- $p$-L)Cl] $\cdot \mathrm{S} 112 \mathrm{R}-\mathrm{N} 118 \mathrm{P}-$ K121A-S122M-L124Y revealed that the introduction of two bulky amino acid residues at positions 112 and 124 within the Sav active site resulted in an approximately $180^{\circ}$ rotation of the pianostool moiety around the $\mathrm{C}_{\text {benzene }}-\mathrm{S}_{\text {sulfonamide }}$ bond. The cofactor becomes more surface-exposed, which may lead to increased solvent exposure of the substrate. [23a]

In conclusion, introduction of a biotinylated pianostool $\mathrm{Cp}$ * Ir catalyst within Sav variants produces ATHases. Directed evolution of such hybrid catalysts using the streamlined optimization protocol for Sav production allows for screening hundreds of Sav variants contained in cfe, hence notably improving the throughput of the process. After only four rounds of directed evolution, two mutants with an improved activity and selectivity on the model cyclic imine substrate were identified. These mutants perform well on a preparative scale and under biphasic reaction conditions, thus implying a wide range of application possibilities.

\section{Acknowledgments}

The author is grateful to Metrohm and the Swiss Chemical Society for the best oral presentation award. The author would like to thank Professor Thomas R. Ward for his supervision and the SNI (Swiss Nanoscience Institute) and SNF (Swiss National Science Foundation) for financial support.

Received: January 22, 2018

[1] H. Krässig, J. Schurz, R. G. Steadman, K Schliefer, W. Albrecht, M. Mohring, H. Schlosser, 'Ullmann's Encyclopedia of Industrial Chemistry', Wiley-VCH, Weinheim, 2002.

[2] a) F. Rudroff, M. D. Mihovilovic, H. Gröger, R. Snajdrova, H. Iding, U. T. Bornscheuer, Nat. Catal. 2018, 1, 12; b) M. D. Truppo, ACS Med. Chem. Lett. 2017, 8, 476; c) M. Hönig, P. Sondermann, N. J. Turner, E. M. Carreira, Angew. Chem., Int. Ed. 2017, 56, 8942; d) J. M. Choi, S. S. Han, H. S. Kim, Biotechnol. Adv. 2015, 33, 1443; d) N. J. Turner, M. D. Truppo, Curr. Opin. Chem. Biol. 2013, 17, 212; e) M. T. Reetz, J. Am. Chem. Soc. 2013, 135, 12480.

[3] L. M. Jarvis, Chem. Eng. News 2014, 94, 12.

[4] M. Breuer, K. Ditrich, T. Habicher, B. Hauer, M. Keßeler, R. Stürmer, T. Zelinski, Angew. Chem., Int. Ed. 2004, 43, 788.

[5] a) J. Renkel, Chiral Amin. Synth. Wiley-VCH, Weinheim, 2010, 1; b) T. C. Nugent, M. ElShazly, Adv. Synth. Catal. 2010, 352, 753.

[6] a) G. Grogan, Curr. Opin. Chem. Biol. 2018 , 43,$15 ;$ b) D. Ghislieri, N. J. Turner, Top. Catal. 2014, 57, 284; c) W. Kroutil, E. M. Fischereder, C. S. Fuchs, H. Lechner, F. G. Mutti, D. Pressnitz, A. Rajagopalan, J. H. Sattler, R. C. Simon, E. Siirola, Org. Process Res. Dev. 2013 17,751

[7] a) N. J. Weise, F. Parmeggiani, S. T. Ahmed, N. J. Turner, J. Am. Chem. Soc. 2015, 137, 12977; b) F. Parmeggiani, S. L. Lovelock, N. J. Weise, S. T. Ahmed, N. J. Turner, Angew. Chem., Int. Ed. 2015, 54, 4608; c) M. M. Heberling, B. Wu, S. Bartsch, D. B. Janssen, Curr. Opin. Chem. Biol. 2013, 17, 250.

[8] a) A. Gomm, E. O'Reilly, Curr. Opin. Chem. Biol. 2018, 43, 106; b) E. E. Ferrandi, D Monti, World J. Microbiol. Biotechnol. 2018, 34, 13; c) H. Brundiek, M. Höhne, 'Transaminases - A Biosynthetic Route for Chiral Amines', in 'Applied Biocatalysis: From Fundamental Science to Industrial Applications: From Fundamental Science to Industrial Applications', Eds: L. Hilterhaus, A. Liese, U. Kettling, G. Antranikian, Wiley-VCH Weinheim, Germany, 2016, pp 199; d) R. C. Simon, N. Richter, E. Busto, W. Kroutil, ACS Catal. 2014, 4, 129.

[9] a) K. Mitsukura, T. Yoshida, in 'Chapter 5 Imine Reductases for Chiral Amine Synthesis', in 'Future Directions in Biocatalysis', Ed. T. Matsuda, Elsevier, Amsterdam, 2017, p. 
97; b) J. Mangas-Sanchez, S. P. France, S. L. Montgomery, G. A. Aleku, H. Man, M. Sharma, J. I. Ramsden, G. Grogan, N. J. Turner, Curr. Opin. Chem. Biol. 2017, 37, 19; c) M. Lenz, N. Borlinghaus, L. Weinmann, B. M. Nestl, World J. Microbiol. Biotechnol. 2017, 33, 199; d) K. Mitsukura, M. Suzuki, K. Tada, T. Yoshida, T. Nagasawa, Org. Biomol. Chem. 2010, 8, 4533; e) K. Mitsukura, M. Suzuki, S. Shinoda, T. Kuramoto, T. Yoshida, T. Nagasawa, Biosci. Biotechnol. Biochem. 2011, 75, 1778.

[10] a) T. Knaus, W. Böhmer, F. G. Mutti, Green Chem. 2017, 19, 453; b) F. G. Mutti, T. Knaus, N. S. Scrutton, M. Breuer, N. J. Turner, Science 2015, 349, 1525.

[11] a) Z. S. Seddigi, M. S. Malik, S. A. Ahmed, A. O. Babalghith, A. Kamal, Coord. Chem. Rev. 2017, 348, 54; b) J. Paetzold, J. E. Bäckvall, J. Am. Chem. Soc. 2005, 127, 17620; c) F. Balkenhohl, K. Ditrich, B. Hauer, W. Ladner, $J$. für Prakt. Chemie/Chemiker-Zeitung 1997, 339. 381.

[12] a) P. Zajkoska, M. Cárdenas-Fernández, G. J. Lye, M. Rosenberg, N. J. Turner, M. Rebroš, J. Chem. Technol. Biotechnol. 2017, 92, 1558; b) N. Scalacci, G. W. Black, G. Mattedi, N L. Brown, N. J. Turner, D. Castagnolo, ACS Catal. 2017, 7, 1295; c) S. Herter, F. Medina, S. Wagschal, C. Benhaïm, F. Leipold, N. J. Turner, Bioorg. Med. Chem. 2017, DOI 10.1016/j. bmc.2017.07.023; d) D. Ghislieri, A. P. Green, M. Pontini, S. C. Willies, I. Rowles, A. Frank, G. Grogan, N. J. Turner, J. Am. Chem. Soc. 2013, 135, 10863 .

[13] a) F. Schwizer, Y. Okamoto, T. Heinisch, Y. Gu, M. M. Pellizzoni, V. Lebrun, R. Reuter, V. Köhler, J. C. Lewis, T. R. Ward, Chem. Rev. 2018, 118, 142; b) M. Pellizzoni, G. Facchetti, R. Gandolfi, M. Fusè, A. Contini, I. Rimoldi, ChemCatChem 2016, 8, 1665; c) J. Bos, G Roelfes, Curr. Opin. Chem. Biol. 2014, 19, 135; d) J. Bos, F. Fusetti, A. J. M. Driessen, G. Roelfes, Angew. Chem., Int. Ed. 2012, 51, 7472; e) J. Podtetenieff, A. Taglieber, E. Bill, E. J. Reijerse, M. T. Reetz, Angew. Chem., Int. Ed. 2010, 49, 5151; f) C.-C. Lin, C.-W. Lin, A C. S. Chan, Tetrahedron: Asymmetry 1999, 10, 1887; g) M. E. Wilson, G. M. Whitesides, J. Am. Chem. Soc. 1978, 100, 306.

[14] a) J. C. Lewis, ACS Catal. 2013, 3, 2954; b) P. J. Deuss, R. Denheeten, W. Laan, P. C. J. Kamer, Chem. - A Eur. J. 2011, 17, 4680; c) M. Allard, C. Dupont, V. Muñoz Robles, N. Doucet, A. Lledós, J. D. Maréchal, A. Urvoas, J. P. Mahy, R. Ricoux, ChemBioChem 2012,
13, 240; d) M. Creus, A. Pordea, T. Rossel, A. Sardo, C. Letondor, A. Ivanova, I. LeTrong, R. E. Stenkamp, T. R. Ward, Angew. Chem., Int. Ed. 2008, 47, 1400; e) T. Ueno, T. Koshiyama, S. Abe, N. Yokoi, M. Ohashi, H. Nakajima, Y. Watanabe, J. Organomet. Chem. 2007, 692, 142; f) Q. Jing, K. Okrasa, R. J. Kazlauskas, Chem. - A Eur. J. 2009, 15, 1370.

[15] a) C. Esmieu, M. V. Cherrier, P. Amara, E. Girgenti, C. Marchi-Delapierre, F. Oddon, M. Iannello, A. Jorge-Robin, C. Cavazza, S. Ménage, Angew. Chem., Int. Ed. 2013, 52, 3922; b) T. K. Hyster, L. Knorr, T. R. Ward, T. Rovis, Science 2012, 338, 500; c) S. D. Khare, Y. Kipnis, P. Greisen, R. Takeuchi, Y. Ashani, M. Goldsmith, Y. Song, J. L. Gallaher, I. Silman, H. Leader, J. L. Sussman, B. L. Stoddard, D. S. Tawfik, D. Baker, Nat. Chem. Biol. 2012, 8 , 294; d) M. Allard, C. Dupont, R. V. Munoz, N. Doucet, A. Lledos, J.-D. Marechal, A. Urvoas, J.-P. Mahy, R. Ricoux, ChemBioChem 2012, 13, 240.

[16] a) T. Heinisch, T. R. Ward, Acc. Chem. Res. 2016, 49, 1711; b) H. Mallin, M. Hestericová, R. Reuter, T. R. Ward, Nat. Protoc. 2016, 11,835 ; c) M. T. Reetz, J. J.-P. Peyralans, A. Maichele, Y. Fu, M. Maywald, Chem. Commun. 2006, 4318; d) C. Letondor, N. Humbert, T. R. Ward, Proc. Natl. Acad. Sci. 2005, 102, 4683.

[17] J. Pierron, C. Malan, M. Creus, J. Gradinaru, I. Hafner, A. Ivanova, A. Sardo, T. R. Ward, Angew. Chem., Int. Ed. 2008, 47, 701.

[18] a) M. Jeschek, R. Reuter, T. Heinisch, C. Trindler, J. Klehr, S. Panke, T. R. Ward, Nature 2016, 537, 661; b) C. Lo, M. R. Ringenberg, D. Gnandt, Y. Wilson, T. R. Ward, Chem. Commun. 2011, 47, 12065.

[19] V. Köhler, J. Mao, T. Heinisch, A. Pordea, A. Sardo, Y. M. Wilson, L. Knörr, M. Creus, J. C. Prost, T. Schirmer, Angew. Chem., Int. Ed. 2011, 50, 10863.

[20] C. M. Thomas, C. Letondor, N. Humbert, T. R. Ward, J. Organomet. Chem. 2005, 690, 4488.

[21] a) A. Pordea, D. Mathis, T. R. Ward, J. Organomet. Chem. 2009, 694, 930; b) A. Pordea, M. Creus, J. Panek, C. Duboc, D. Mathis, M. Novic, T. R. Ward, J. Am. Chem. Soc. 2008, 130, 8085.

[22] a) M. T. Reetz, Top. Organomet. Chem. 2009 , 25, 63; b) J. Collot J. Am. Chem. Soc. 2003, 125, 9030 .

[23] a) M. Hestericová, T. Heinisch, L. AlonsoCotchico, J.-D. Maréchal, P. Vidossich, T. R. Ward, Angew. Chem., Int. Ed. 2018, 10.1002/ anie.201711016; b) Y. Okamoto, V. Köhler, T.
R. Ward, J. Am. Chem. Soc. 2016, 138, 5781; c) M. Hestericová, M. R. Correro, M. Lenz, P. F. X. Corvini, P. Shahgaldian, T. R. Ward, Chem. Commun. 2016, 52, 9462; d) Y. Okamoto, V. Köhler, C. E. Paul, F. Hollmann, T. R. Ward, ACS Catal. 2016, 6, 3553; e) T. Quinto, D. Häussinger, V. Köhler, T. R. Ward, Org. Biomol. Chem. 2015, 13, 357; f) T. Heinisch, K. Langowska, P. Tanner, J.-L. Reymond, W. Meier, C. Palivan, T. R. Ward, ChemCatChem 2013, 5, 720; g) V. Köhler, Y. M. Wilson, M. Dürrenberger, D. Ghislieri, E. Churakova, T. Quinto, L. Knörr, D. Häussinger, F. Hollmann, N. J. Turner, T. R. Ward, Nat. Chem. 2013, 5, 93; h) M. Dürrenberger, T. Heinisch, Y. M. Wilson, T. Rossel, E. Nogueira, L. Knörr, A. Mutschler, K. Kersten, M. J. Zimbron, J. Pierron, et al., Angew. Chem. Int. Ed. 2011, 50, 3026; i) C. Letondor, N. Humbert, T. R. Ward, Proc. Natl. Acad. Sci. 2005, 102, 4683.

[24] a) J. G. Rebelein, T. R. Ward, Curr. Opin. Biotechnol. 2018, 53, 106; b) M. Jeschek, S. Panke, T. R. Ward, Trends Biotechnol. 2018, 36, 60; c) S. C. Hammer, A. M. Knight, F. H. Arnold, Curr. Opin. Green Sustain. Chem. 2017, 7, 23; d) T. K. Hyster, T. R. Ward, Angew. Chem., Int. Ed. 2016, 2; e) H. Renata, Z. J. Wang, F. H. Arnold, Angew. Chem., Int. Ed. 2015, 54, 3351 .

[25] a) M. T. Reetz, 'Recent Advances in Directed Evolution of Stereoselective Enzymes', in 'Directed Enzyme Evolution: Advances and Applications', Eds. M. Alcalde, Springer, Cham, 2017; b) F. H. Arnold, Angew. Chem. Int. Ed. 2017, doi: 10.1002/anie.201708408; c) H. Renata, Z. J. Wang, F. H. Arnold, Angew. Chem., Int. Ed. 2015, 54, 3351; d) A. Ilie, M. T. Reetz, Isr. J. Chem. 2015, 55, 51; e) M. S. Packer, D. R. Liu, Nat. Rev. Genet. 2015, 16, 379 , f) C. A. Denard, H. Ren, H. Zhao, Curr. Opin. Chem. Biol. 2015, 25, 55; g) E. M. Brustad, F. H. Arnold, Curr. Opin. Chem. Biol. 2011, 15, 201; h) K. Chen, F. H. Arnold, Proc. Natl. Acad. Sci. U. S. A. 1993, 90, 5618; i) W. P. C. Stemmer, Nature 1994, 370, 389.

[26] a) B. D. Bennett, E. H. Kimball, M. Gao, R. Osterhout, S. J. Van Dien, J. D. Rabinowitz, Nat. Chem. Biol. 2009, 5, 593; b) Y. M. Wilson, M. Dürrenberger, E. S. Nogueira, T. R. Ward, J. Am. Chem. Soc. 2014, 136, 8928.

[27] G. Kada, K. Kaiser, H. Falk, H. J. Gruber, Biochim. Biophys. Acta 1999, 1427, 44.

[28] V. M. Robles, M. Dürrenberger, T. Heinisch, A. Lledós, T. Schirmer, T. R. Ward, J.-D. Maréchal, J. Am. Chem. Soc. 2014, 136, 15676. 